\title{
Economology and Actuarial Accounting in Digital Economy
}

\author{
Anton I. Shigaev \\ associate professor (docent), doctor of economic sciences, \\ School of management accounting and controlling \\ Kazan Federal University \\ Kazan, Russia \\ AIShigaev@kpfu.ru
}

\author{
Vitaly B. Ivashkevich \\ professor, doctor of economic sciences, \\ School of management accounting and controlling \\ Kazan Federal University \\ Kazan, Russia \\ VBIvashkevich@kpfu.ru
}

\begin{abstract}
The paper aims to define the content and main models of economology and actuarial accounting in the conditions of digital economy. The results of the study allow one to define economology as a science integrating different bodies and directions of knowledge of managerial economics, integrated accounting, analysis and audit to improve the effectiveness of managerial decision making and corporate management. The paper analyzes the definition and content of the modern concepts of economology and actuarial accounting, which utilize contemporary digital computing and information technologies and use the principles of balancing to apply economic logic in managerial decision making. In economology and actuarial accounting, a balance can be considered as the equilibrium between the counting and calculation relations and changes in their opposite values, and one of the principles embedded in the arrangement of the computing mechanisms of digital economy. Economic and mathematical models, indicators and procedures of balance management and actuarial accounting as the foundation of economology can be used in all major aspects of enterprise economy management. The digital economy provides the required informational base, ensures the speed and efficiency of data processing, significantly expands the capabilities of management decision making under numerous limitations.
\end{abstract}

Keywords - economology; digital economy; actuarial accounting; balance management; accounting theory; accounting models

\section{INTRODUCTION}

Economology as a science based on the use of economic information for enterprise management was first determined by Lev (Leon) Ivanovich Gomberg (1866-1935). Lev Gomberg was the well-known Russian scientist who worked in the field of accounting and balance studies and was the member of the International Association of Accountants in the beginning of the last century. He believed that the main content and purpose of this science is the study of the economic activity of a single enterprise by describing it in monetary evaluation [6].

Economology as an independent direction in accounting science and practice did not receive public recognition at that time, mainly because it required significant cost for the preparation of the respective information. At that time, accounting and analysis in Russia and abroad were conducted, mainly, manually or with the use of the simplest computing devices.

Now the situation is substantially different. Modern computers and information systems have virtually removed the issues of labor intensity and timeliness of the formation and use of digital information from the agenda. The digital economy not only almost completely solves this problem, but also involves the extended capabilities of using numerical data and applying actuarial accounting methodology for management, especially at the enterprise level. These capabilities were previously unrealistic.

\section{RESULTS AND DISCUSSION}

The term "Economology" was suggested by Lev Gomberg in the beginning of the last century. He called accounting science "economology", i.e. economic logics and divided it into six components: valuation, inventory, estimate (budget), accounting (bookkeeping), reporting, and control [13, 18]. Economology deals with budget principles, the evaluation and estimation of economic assets and operations, and the formulas by which inventory is made $[2,3,11]$.

According to Gomberg L., the subject of economology is production, financial and economic activity of a business entity, which is legally separate and prepares an individual balance sheet $[4,5]$. Economology determines the composition and content of monetary information for the management of this activity as well as the methods for obtaining and analyzing this information. Economology also studies and assesses the economic position of the business entity, based on its past and present state with a mandatory orientation toward the future.

A distinctive feature of economology consists in an integrated approach to the formation and study of economic information, ensuring the interrelation among planned, actual and forecasted indicators, and the extensive use of balance methods for controlling the reliability of economic indicators $[4,6]$. Nowadays this approach also has to include the information and financial modeling of an economic entity without which the modern management of an economic enterprise is impossible $[9,20]$. 
Although a single approach to defining the digital economy as a common system is yet to come, there is hardly any doubt that digital economy represents an economic activity with the use of modern digital computing, web and information technologies.

The digital economy implies the application of modern methods of managing the economy with the use of contemporary digital computing technologies for generating the required digital data. The digital economy, to a greater extent and with better information capabilities, ensures the more efficient use of existing factors of production and distribution in order to maximize the fulfillment of society's needs for goods and services. The digital economy allows to solve the tasks of selecting products, goods and services, and the tasks of optimizing the use of required material, labor and financial resources more effectively, efficiently and skillfully at all levels of management. That is why the basic postulates and principles of economology as a science about the digital economy of a separate economic entity, as well as the theory and practice of information support of value based enterprise management become attractive and increasingly important nowadays.

Economology, as the part of digital economy limited by the sphere of an enterprise, needs further development of its basic postulates, methods and techniques. In the initial representation, it was considered as the theoretical basis of balance studies in its broad generalized concept. It had not only included the rules of the preparation and analysis of a balance sheet, but also required the ensuring the balance (balancing) of all main economic indicators of the activity of an enterprise: cash inflow and outflow, revenues and expenses, costs and results, materials consumption and production output, etc. $[1,14,19]$.

Nowadays the balance sheet is considered as the basis of the information and financial model of a business entity and therefore it retains the right to be included into the composition of the components of economic modeling, including predicative modeling. Balance studies are also reviving and form an important direction for the development of the accounting science. However, while this concept is often represented as a methodical basis for the preparation and analysis of the balance sheet and other financial statements, we believe that it has long outgrown these limitations.

Professors Kovalevs quite reasonably believe that the main purpose of balancing is to explain how public financial reporting can be used as an evidence base that allows to form an idea about an economic entity from the standpoint of its investment and (or) counterparty attractiveness. [10]. The evidence base of the financial position and the economy of an enterprise is much broader than the evidence base developed by the application of the rules for the preparation and analysis of financial statements. And given the capabilities of the digital economy, this concept can be further expanded.

If one starts from a literal understanding of the meaning behind the concept of balancing, one can draw a conclusion that this concept cannot be limited by only financial planning and reporting. The balance is primarily an equilibrium in bookkeeping. According to he old Russian accountant A.P.
Pelenkin, the balance is "the equality between the counting and calculation relations and changes in their opposite values, the principle embedded in the arrangement of the counting mechanism, on which the rational bookkeeping is justified" [15]. In our opinion, modern balance management in digital economy should possess these characteristics. This will ensure:

- generalization, interconnection, counting control of the correctness of the formation and systematization of planning and accounting indicators, different in content and purpose, and used to manage the enterprise;

- concise, comprehensive, and sufficiently clear presentation of information required for the characterization of an economic entity, as well as the respective presentation of indicators and procedures used to manage its activities with a goal to optimize economic decisions;

- the possibility of using the principles of multifactor modeling, analytical expression and reflection of the relationship between the phenomena studied, including the development of predictive models.

Economic and mathematical models, indicators and procedures of balance management can be used in all major aspects of enterprise economy management. They are of particular importance for predicate modeling. This is especially important for modern management, which always assumes a vision of the future. The deterministic factor models, stochastic models based on regression equations, pricing models, valuations of shares and other securities, optimal cash balance, discounted cash flows, valuation of financial assets and measures of the return on capital employed can be more informative and versatile in contemporary economology that is functioning under the principles of digital economy. The digital economy provides the required information base, ensures the speed and efficiency of data processing, significantly expands the capabilities of management decision making under numerous limitations, and enables the optimization of managerial decisions in the specific conditions of an enterprise.

In the conditions of digital economy, the new conditions of the capital market functioning put forward the task of preserving and increasing the economic value of the wealth of its participants, expressed in the form of capital investments in business entities. To solve this task and make rational decisions on capital investments, capital market participants need information about the ability of commercial organizations to create economic value and generate cash flows in the future. Thus, in contemporary economy, there is a need for a new type of accounting, namely actuarial accounting, aimed at reducing the uncertainty of the financial future and generating information for the respective evaluation of economic value and future cash flows.

At the same time, to solve the new task of preserving and increasing the economic value of the investments of capital providers (owners and creditors) in business entities and, consequently, the task of increasing the economic value of equity capital, business entities began to set the goals of creating economic value, generating future cash flows and 
increase their future performance and value. The orientation of corporate governance on the achievement of these goals contributed to the emergence and development of the new methods and models of value-based management, for the implementation of which it is necessary to apply the methodology of actuarial accounting and generate the information about the future of business entities, including their future performance.

In the conditions of a new economic environment and the intent of investors, owners and lenders to maximize the value of their wealth measured in terms of economic value, the managers of business entities have to implement new methods and models for managing cash flows and the capitalization of an enterprise. To implement these methods and models, accountants should be able to make certain actuarial calculations with the use of discounting techniques and prepare special accounting and analytical information that allows to evaluate the economic value created, assess the prospects for its growth, forecast future cash flows of the organization, and compute the economic value of equity as the difference between the economic value of the organization's assets and the fair value of liabilities (loans and credits) [17, $12]$.

In our opinion, actuarial accounting is an accounting aimed at the formation of information that potential and present investors, lenders and other capital providers need for the evaluation of created economic value and future cash flows in making decisions about investments, providing loans, and other decisions about providing resources to business entities. Managers use the information of actuarial accounting for the management of investment attractiveness and economic value of their entity [17].

In actuarial accounting, the formation of information required for the assessment of the economic value and future cash flows of a business entity is being done in accordance with the modern theory of corporate finance, which distinguishes between operating and financing activities.

Financing activities are the activities performed to attract and return financial resources (equity and debt), which are used to finance operating activities. Operating activities are activities aimed at the creation of economic value. In the course of operating activities, managers invest the financial resources into various operations to increase the wealth of investors (owners), expressed in the economic value of the organization. Operating activities encompass the operations of the production and sale of products and services.

The information of actuarial accounting is disclosed in actuarial financial statements, which present the information on economic resources of an organization and claims to those resources, comprehensive financial results and cash flows of the organization grouped into the categories of operating and financing activities. The new model of actuarial financial reporting is aimed at generating information on the financial position of the organization (economic resources and claims to them) and its change that is useful to existing and potential investors and creditors in making decisions about investing resources in the organization.
Main financial statements and the balance generalization in actuarial accounting are based on two types of balance equations. In accordance with the static balance equation of actuarial accounting, the value of net operating assets equals the sum of net financial liabilities (net financial obligations) and equity. The static balance equation of actuarial accounting can be represented by the following formula:

$$
\begin{aligned}
& \text { Net Operating Assets = Net Financial Obligations + } \\
& + \text { Common Shareholders' Equity }
\end{aligned}
$$

The static balance equation of actuarial accounting can be used to prepare an actuarial balance sheet. In this balance sheet, in accordance with the general orientation of actuarial accounting and corporate finance on the distinction between operating and financing activities, the assets and liabilities of the organization are grouped into the categories of operating and financing assets and liabilities [16, 17]. An example of actuarial balance sheet of one of well-known Russian corporations is presented in Table I.

TABLE I. ACTUARIAL BALANCE SHEET OF JOINT STOCK COMPANY " $\mathrm{X}$ " (IN MILLIONS OF RUBLES)

\begin{tabular}{|l|c|c|c|}
\hline \multicolumn{1}{|c|}{ Balance sheet items } & $\begin{array}{c}\text { Dec. 31, } \\
\mathbf{2 0 1 6}\end{array}$ & $\begin{array}{c}\text { Dec. 31, } \\
\mathbf{2 0 1 5}\end{array}$ & $\begin{array}{c}\text { Dec. 31, } \\
\mathbf{2 0 1 4}\end{array}$ \\
\hline \multicolumn{2}{|c|}{ NET OPERATING ASSETS } \\
\hline Operating assets & 47021 & 41519 & 30531 \\
\hline Operating liabilities & 5397 & 4837 & 5398 \\
\hline Total net operating assets & 41623 & 36681 & 25133 \\
\hline \multicolumn{1}{|c|}{ NET FINANCIAL OBLIGATIONS } \\
\hline Financial assets & 262 & 401 & 759 \\
\hline $\begin{array}{l}\text { Financial obligations } \\
\text { (liabilities) }\end{array}$ & 29842 & 21463 & 12506 \\
\hline $\begin{array}{l}\text { Total net financial obligations } \\
\text { Common shareholders' equity }\end{array}$ & 29579 & 21062 & 11746 \\
\hline $\begin{array}{l}\text { Total common shareholders' } \\
\text { equity and net financial } \\
\text { obligations }\end{array}$ & 41623 & 36681 & 25133 \\
\hline
\end{tabular}

According to the dynamic balance equations of actuarial accounting, free cash flow from the viewpoint of operating activity is equal to the free cash flow from the viewpoint of financing activity. In other words, the total net cash inflow (outflow) from operating activities equals the overall amount of net outflow (inflow) of funds from financing activities. At the same time, cash flow from operating activities less cash flow from investing activities (that is, less cash investments in long-term operating assets) equals the amount of cash flows from transactions with creditors and shareholders.

The dynamic balance equation of actuarial accounting can be represented by the following formula: 
Operating Income $-\Delta$ Net Operating Assets $=$ Net Financial

Expense $-\Delta$ Net Financial Obligations + Dividends - $\Delta$ Common Shareholders' Equity

Table II represents an example of actuarial balance sheet of cash flows of the same well-known Russian corporation prepared with the use of the dynamic balance equation of actuarial accounting expressed in formula 2. In this balance sheet, the amount of free cash flow from the viewpoint of operating activity is equal to the amount of free cash flow from the viewpoint of financing activity.

TABLE II. ACTUARIAL BALANCE SHEET OF CASH FLOWS OF JOINT STOCK COMPANY "X" (IN MILLIONS OF RUBLES)

\begin{tabular}{|c|c|c|}
\hline Balance sheet items & 2016 & 2015 \\
\hline \multicolumn{3}{|c|}{ OPERATING ACTIVITY } \\
\hline Operating income & -2051 & 2805 \\
\hline Change in net operating assets & 4942 & 11548 \\
\hline FREE CASH FLOW & -6993 & -8743 \\
\hline \multicolumn{3}{|c|}{ FINANCING ACTIVITY } \\
\hline \multicolumn{3}{|c|}{ Transactions with debtholders } \\
\hline Net financial expense & 959 & 281 \\
\hline Change in net financial obligations & 8517 & 9316 \\
\hline Net cash flow to debtholders & -7559 & -9034 \\
\hline \multicolumn{3}{|c|}{ Transactions with shareholders } \\
\hline Dividends & 573 & 330 \\
\hline $\begin{array}{l}\text { Change in common stockholders' equity as } \\
\text { a result of initial public offering and the } \\
\text { transactions with treasury shares }\end{array}$ & -8 & -39 \\
\hline Net cash flow to shareholders & 566 & 291 \\
\hline FREE CASH FLOW & -6993 & -8743 \\
\hline
\end{tabular}

The actuarial balance sheet of cash flows can also be prepared by the transformation of a regular cash flow statement. In this case, the dynamic balance equation of actuarial accounting can be expressed by a different formula:

$$
\mathrm{C}-\mathrm{I}=\mathrm{F}+\mathrm{d}
$$

where:
$\mathrm{C}$ - Cash flow from operations
I - Cash flow from investing activity (Cash investments)
$\mathrm{F}$ - Cash flow to debtholders
$\mathrm{d}-$ Cash flow to shareholders

All components of this equation are also reproduced in the actuarial balance sheet of cash flows as shown in another example of actuarial balance sheet of cash flows of the same Russian corporation presented in Table III.

TABLE III. ACTUARIAL BALANCE SHEET OF CASH FLOWS OF JOINT STOCK COMPANY " $X$ " PREPARED ON THE BASIS OF THE REGULAR STATEMENT OF CASH FLOWS (IN MILLIONS OF RUBLES)

\begin{tabular}{|c|c|c|}
\hline Balance sheet items & 2016 & 2015 \\
\hline \multicolumn{3}{|c|}{ OPERATING ACTIVITY } \\
\hline Cash flow from operations (C) & 3118 & 2145 \\
\hline \multicolumn{3}{|c|}{ INVESTING ACTIVITY } \\
\hline Cash flow from investing activity (I) & 5623 & 10021 \\
\hline FREE CASH FLOW & -2505 & -7876 \\
\hline \multicolumn{3}{|c|}{ FINANCING ACTIVITY } \\
\hline \multicolumn{3}{|c|}{ Transactions with debtholders } \\
\hline Cash flow to debtholders $(\mathrm{F})$ & -3100 & -8197 \\
\hline \multicolumn{3}{|c|}{ Transactions with shareholders } \\
\hline Cash flow to shareholders (d) & 596 & 321 \\
\hline FREE CASH FLOW & -2505 & -7876 \\
\hline
\end{tabular}

In overall, the regular preparation and analysis of actuarial balance sheets are of great importance for modern business entities. Actuarial balance sheets and other forms of actuarial financial statements allows to calculate the economic value of an organization, analyze the financial performance of an organization, determine and monitor the drivers of economic value, and significantly improve the quality of cash flow management and budgeting. In the conditions of digital economy, the information of actuarial accounting disclosed in actuarial financial statements can form the informational basis for the evaluation of the economic value of shareholders' equity and business entity.

\section{CONCLUSIONS}

In economic science, a dialectical development follows a spiral. Often previously formed concepts, terms and categories receive a new content. The capabilities of modern computing technology and the systems of the formation and use of the information obtained under this technology provide another argument regarding the need to combine integrated accounting, analysis and audit into a unified scientific discipline "Economology" that studies the production, financial and economic activities of a stand-alone enterprise by presenting and valuing these activities in monetary units. All managers and top managers of enterprises, external investors and financial consultants should know the foundations of this science and be able to use its principles and economic logic while integrating the theory and practice of accounting, analysis and control. 
The name of this science may be different, but in our opinion it is obvious that it is necessary to integrate different bodies and directions of knowledge of managerial economics to improve the effectiveness of managerial decision making. In addition to generalization, the combination of various components of the knowledge of managerial economics will provide a synergetic effect from the performance of different calculations in accounting, analysis, external and internal control on a digital basis $[7,8]$.

Lev Ivanovich Gomberg was the first to propose to call this section of the economic science on the economy of an enterprise by the special term "Economology". In the 1920s, he was forced to emigrate to Switzerland. There he continued and intensified his scientific and public activities, published a number of books on French and German languages, gained international recognition as the prominent theorist in accounting and balance management, was elected a corresponding member of the Academic Society of Accountants and a full member of the International Association of Accountants. The preservation of the term "economology" as the name of the accounting and analytical science proposed by L.I. Gomberg that corresponds to the basic principles of the digital economy, would be, among other things, a token of gratitude and recognition to the prominent scientist, one of the leading intellectuals of the European accounting system.

\section{Acknowledgment}

The authors are grateful to the faculty of the School of management accounting and controlling of Kazan Federal University and the participants of the International economic forum "Economics in changing world" (April, 2018) for their helpful comments and suggestions on an earlier draft of the paper.

\section{References}

[1] J. Baetge, Balance studies, translated from German. Moscow: Accounting, 2000.

[2] M. Cîndea, J.M. Cîndea, G. Ciurariu, A. Trifu, and C. Durdureanu, "History of accountancy. A chronological approach," 2011 International Conference on Financial Management and Economics. IACSIT Press, Singapore. vol.11, 2011.

[3] L. Gomberg, L'économologique (scientifique comptable) et son histoire (Scientific accounting and its history). Genéve: Société Général d'Impr., 1912.
[4] L.I. Gomberg, "About the object of bookkeeping" (Ob obyekte Schetovodstva), in Bookkeeping (Schetovodstvo), vol. 11-12, pp. 147153, 1899.

[5] L.I. Gomberg, "Bookkeeping and its scientific system" (Schetovodstvo i ego nauchnaya sistema), in Bulleten of Moscow Society of Accountants, vol. 4, pp. 19-26, 1909.

[6] L.I. Gomberg, "Bookkeeping and political economy" (Schetovodstvo i politicheskaya economika), in Bookkeeping (Schetovodstvo), vol. 10$16,1897$.

[7] C. Holroyd, K.S. Coates, The Global Digital Economy: A Comparative Policy Analysis. - New York, Amberst: Cambria Press, 2015

[8] S. Huibregtse, A. Sood, Digital Economy Handbook 2016: Tax, Transfer Pricing and other Legal Aspects of Business Configurations 1st Edition. - Transfer Pricing Technologies BV, TPA Global, CreateSpace Independent Publishing Platform, 2016.

[9] V.B. Korneychuk, Informational economy. Saint Petersburg: Piter, 2006.

[10] V.V. Kovalev, Vit.V. Kovalev, Analysis of balance (analiz balansa). Moscow: Prospect, 2016.

[11] M.I. Kuter, V.Y. Sokolov, "Russia," in "A global history of accounting, financial reporting and public policy: Eurasia, the Middle East and Africa," Studies in the Development of Accounting Thought, Ed. By Previts G., Walton P., Wolnizer P. Emerald. Volume 14D, pp. 75-105, 2012.

[12] G.V. Lepadatu, "The actuarial accounting in the modern financialaccounting management with applications to the corporate units in the steel industry," in Metalurgia international, vol. 13, issue 2, pp. 5-11, 2008.

[13] R. Mattessich, Two hundred years of accounting research. An international survey of personalities, ideas and publications (from the beginning of the nineteenth century to the beginning of the twenty first century). Routledge, Taylor \& Francis: New York, NY, 2008.

[14] B.E. Needles, M. Powers, M.L. Frigo, A.I. Shigaev, "Integrated reporting and sustainability reporting: An exploratory study of high performance companies," in "Performance measurement and management control: contemporary issues,” Edited by: Marc J. Epstein, Frank Verbeeten, Sally K. Widener. Studies in managerial and financial accounting, Volume 31, pp. 41-81. Emerald Group Publishing Limited, 2016.

[15] A.P. Pelenkin, What is a balance in general and in accounting in particular (Chto takoe balance voobsche i buhgalterskii $\mathrm{v}$ chastnosti). Saint Petersburg, 1898.

[16] S. Penman, J.A. Ohlson, et al., "A framework for financial reporting standards: Issues and a suggested model," in Accounting Horizons, Volume 24, Issue 3, pp. 471-485, 2010.

[17] A.I. Shigaev, Actuarial accounting and the use of its data for management (Aktuarniy uchet $\mathrm{i}$ ispolzovanie ego dannikh dlya upravleniya). Moscow: Magister, Infra-M, 2011.

[18] Y.V. Sokolov, V.V. Kovalev, "Russia," in The history of accounting: an international encyclopedia, M. Chatfield and R. Vangermeersch, Eds. New York: Garland Publishing, Inc., 1996, p. 508.

[19] K.Y. Tsigankov, Essays on the theory and history of accounting (Ocherki teorii i istorii buhgalterskogo ucheta). Moscow: Magister, 2009

[20] D.L. Volkov, Theory of value based management: financial and accounting aspects. Saint Petersburg, SPbGU Publishing, 2007 